\title{
保育・教育思想に基づく保育施設の空間特性 モンテッソーリ教育とハンガリーの保育実践を対象として \\ SPATIAL CHARACTERISTICS OF CHILD CARE FACILITIES WHICH BASED ON A THOUGHT OF CHILD CARE AND EDUCATION
}

Case study on the Montessori education and the Hungarian childcare practice theory

\author{
白川 賀津子*，定行 まり子** \\ Kazuko SHIRAKAWA and Mariko SADAYUKI
}

\begin{abstract}
Recently society requires maintaining the quality of child care from architectural viewpoint. The purpose of this research is to clarify the spatial characteristics which based on childcare and educational ideals of each child care facilities. On the basis of "A national guideline for daycare center for children", each child care facilities sometimes adopts specific educational thought. Therefore in this study particularly focuses on two educational methods, "The Montessori education" and "The Hungarian childcare practice theory" which are highly adopted in Japan. To know the spatial characteristics of each educational thought should be important to keep a quality of the future child care environment.
\end{abstract}

\section{Keywords: Child carefacility, Spatial characteristic, Educational thought, TheMontessori education, TheHungarian childcarepracticetheory \\ 保育施設, 空間特性, 教育思想, モンテッソーリ教育, ハンガリーの保育実践}

\section{1. はじめに \\ 1-1 背景と目的}

待機児童問題が未だ解決をみない現在，保育環境をめぐっては改 めてその質が問い直される局面を迎えている。保育・教育現場では, 質の向上に向けた取り組みがおこなわれており, 建築分野からの検 討も必要とされるところである。

日本では保育所保育指針（以下「保育指針」）に基づき，保育がお こなわれており注1), どのような保育を提供すべきかが定められてい る。保育の質を保つという観点からは，空間もこれに沿って備えら れるべきであるが, 実際には必ずしも実現されているとは言い難い。 「保育指針」には，具体的方法論の明記はなされておらず注 2), 空間 の評価スケール注 3)に該当するものも無いためである 1) 3)。

保育施設のなかには, 保育実践や空間特性における具体的方法論 を特定の保育・教育思想に求める者もある。全日本私立保育園連盟 加盟園の保育施設 2,176 件を対象に昨年末実施したアンケート調査 でも, 回答が得られた 364 件（回収率 16.7\%）のうち「何らかの保 育・教育思想（思想家・メソッド）を参考としている」と答えた保 育施設が 194 件 $(53.2 \%)$ にのぼり, なかでもモンテッソーリ教育, ハンガリーの保育実践の採用例が多くみられた（図 1)。これらの思 想における著作では, 保育実践や空間における具体的用件が示され
ている。保育・教育思想は一般的には特徵的なものと捉えられるが, アンケート結果からは, 特定の思想で重視される保育実践や空間特 性が,「保育指針」に基づく保育をおこなう一般園でも取り入れられ ていることが示唆された。すなわち，「保育指針」と思想の間には共 通性があるとも考えられる。そこで本稿では, 実態として採用例の 多かったモンテッソーリ教育とハンガリーの保育実践のふたつの思 想に着目し，思想に基づく空間特性が注 4)，「保育指針」に基づく一 般園にとっての良質な空間の在り方のひとつとしても提示できるも のであるかについて明らかにすることを目的とする。

\section{1-2 既往研究と本稿の位置づけ}

保育・教育理念と空間の関わりについての総括的な研究は, 保育・ 教育学領域では, 子どもの行動に保育空間と保育理念が影響するこ とを明らかにした今川 4)の研究, 建築学領域では, 保育施設におけ る生活者の行動調查から保育方法と保育空間の関わりを考察した遠 矢ら 5の研究があるが, 保育・教育学, 建築学のいずれの領域でも 乏しい状況にあるといえる。一方, 保育実践のうち, 保育形態と空 間構成との関わりを扱ったものとして, 細谷ら 6)の異年齢交流を誘 発する空間についての知見や, 西本ら 7)よる異年齢保育のコーナ 一設定サイクルについて論じた研究など, 特に「異年齢保育」に着

\footnotetext{
* 日本女子大学大学院人間生活学研究科生活環境学専攻 大学院生・修士 (工学)

** 日本女子大学住居学科 教授・博士 (工学)

Grad. Student, Graduate School of Human Life Science, Division of Living Environment, Japan Women's University, M. Eng.

Prof., Dept. of Housing and Architecture, Japan Women's University, Dr. Eng.
} 
目した研究がおこなわれてきており, 核家族, 少子化などの社会的 背景からも重要なものである。また, 特定の保育・教育思想を扱っ た研究では, 保育・教育学領域では幅広くおこなわれているものの, 建築学領域からの研究は伊藤 ${ }^{8}$ によるフレーベル研究, 川上ら9)に よるシュタイナー研究など, 思想に拠る空間特性の基礎的研究に留 まり, 十分とは言い難い。モンテッソーリ教育については, 神成ら 10)が実践園での事例調查から教育思想に相応しい空間計画の, 高橋 ら 11)がモンテッソーリ自身の記述をメソッドの基本的原理と捉え, 実践園と非実践園の比較から, 建築・設備・家具・道具などの主に $3 \sim 6$ 歳児を対象とした物的環境の基本的知見を示している。各国特 有の保育・教育思想としては, 橋本ら 12)によるイタリアのレッジ ヨ・エミリア幼稚園, 山田・本杉・千島ら 13) 15)によるフィンランド のパイバゴディ就学前施設などの研究が僅かにあるばかりで, ハン ガリーの保育実践についての建築的視点からの既往研究は未だない。

保育・教育思想を扱った既往研究では, 前述のとおり思想の原理 に基づく空間を扱うものが多い。しかし本稿では, 日本の保育施設 への応用を前提としているため, 保育・教育思想を原理そのもので はなく, 文化的背景に伴って日本で独自に発展したものとして扱い, そのうえで空間特性の考察をおこなう注 5)

\section{2. 研究の方法}

(1)出現言語比較, (2)アンケート調查, (3)空間事例の 3 点から考察 をおこなう。(1)では保育・教育思想の一般的な基本原理を得るため に, 各思想の代表的文献から出現言語の抽出をおこなう。同様に「保 育指針」の記述からも出現言語の抽出をおこない, そのうえで, 思 想独自にみられた出現言語における各思想の特異性, 各思想と「保 育指針」との共通言語の出現状況から両者の共通性について考察寸 る。次に(1)で得た思想独自の出現言語を用いた質問項目により, (2) のアンケート調查を実施し, 実施園の回答の有意性から各思想の空 間特性の特異性を, 全体回答から各思想と「保育指針」との空間特 性の共通性をみる。以上の考察から得られた各思想の空間特性が実 際の空間に反映される際の具体例を, (3)各思想の実施園の空間事例 にて提示したうえまとめをおこなう。

\section{3. 出現言語にみる各思想の特異性と「保育指針」との共通性 3-1 出現言語の抽出}

モンテッソーリ教育では, その基本原理を示した『モンテッソー リ・メソッド』16), 解説書にあたる『モンテッソーリ・メソッド入 門』17), 幼児, 乳児の保育に詳しい『幼児の秘密』18), 『いのちのひ みつ』19)を, ハンガリーの保育実践では, 幼児の教育プログラムを 示した『ハンガリー保育園の教育プログラム』20), 乳児の保育に詳 しい『新訂乳児の保育・幼児の保育』21)を両思想の代表的文献とし て捉え, 抽出の対象とした (表 1)。これらの文献では主に保育・教 育内容における記述を対象に, 一方で「保育指針」は全文を対象に 名詞・複合名詞の抽出をおこなった。抽出言語は内容ごとに $6 つ に$ 分類し, 出現回数の高い順に並べ, 図 2 とした。

\section{3-2 出現言語における各思想の特異性}

6 つのグループのうち「保育の環境」〈室・家具・設え〉と, 「教 育に関わる事項」〈教育 1 〉〈日常動作〉グループで出現した言語の
殆どが両思想から抽出されたものであった。特に〈室・家具・設え〉 では物的環境について, 〈教育 1 〉では教具や遊びの種類についての 具体的方法論を示す言語が並んだ。

思想別にみると，モンテッソーリ教育では「養護に関わる事項」 〈発達〉グループ, 「教育に関わる事項」〈教育 2 , 〈日常動作〉グ ループなどで, モンテッソーリ教育からの抽出によるものが多い。 また, 特定の活動が集中的にみられる時期や現象を表す〈発達〉グ ループの「敏感期」や「集中現象」, 日常動作を美しく丁寧におこな う〈日常動作〉グループの「線上遊戯」,「優雅」,「平衡・均整」な ど，モンテッソーリ教育に独自の言語もみられた。

ハンガリーの保育実践では,「保育の環境」〈設備〉グループ, 「養 護に関わる事項」〈健康・衛生〉〈関わり〉〈情緒〉グループなどで出 現がみられた。また,「空気入替」,「室温変化」,「自然照明」などの 衛生環境, 「従属関係」, 「心理的安心感」などの心理的愛着形成を重 視する思想の特徴を表す言語もみられた。思想独自にみられたこれ らの言語は, 各思想の保育・教育の基本原理における特異性を表す ものと示唆された。

\section{3-3 出現言語における各思想と「保育指針」の共通性}

「保育指針」からの抽出言語のうち, 図 2 下線部で示した言語は 各思想にも出現した言語で, 各グループに幾つかの共通言語が見受 けられた。例えば「保育のねらい」主体性・自我〉グループや, 〈社 会性〉グループなどが該当し, 子どもの主体的な自己活動や, 集団 生活での社会性が三者に共通して重視されていることを示した。ま た,「保育の環境」〈保育環境〉グループなどでも共通言語が多数み られた。出現言語比較では, 各思想と「保育指針」の間に幾つかの 共通性がみられたことから,「保育指針」が各思想を包含するもので あることが示唆された。

\begin{tabular}{|c|c|c|c|}
\hline No. & 教育思想の種別※1 & $\mathrm{n}=194$ (複数回答) & 割合 (\%) \\
\hline 1 & \begin{tabular}{|l} 
モンテッソーリ \\
(イタリア)
\end{tabular} & 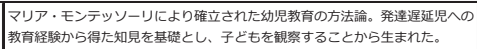 & $21.60 \%$ \\
\hline 2 & $\begin{array}{l}\text { ハンガリーの保育実践※2 } \\
\text { (ハンガリ-) }\end{array}$ & 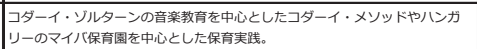 & $18.60 \%$ \\
\hline 3 & $\begin{array}{l}\text { レッジョ・エミリア } \\
\text { (イタリア) }\end{array}$ & $\begin{array}{l}\text { イタリアアのレッジョ・エミリア市自治体や広管围の地域の取組み、参加型協議 } \\
\text { により培われた教育法。 }\end{array}$ & $11.30 \%$ \\
\hline 4 & フレーベル (ドイツ) & $\begin{array}{l}\text { フリードリヒ・フレーベルによる教育思想、子どもが生まれながらに持つ神性 } \\
\text { を自らが発揮することこそが重要と唱えた。 }\end{array}$ & $9.80 \%$ \\
\hline 5 & シュタイナー (ドイツ) & ルドルフ・シュタイナーによる人智学に基づく教育思想。 & $8.20 \%$ \\
\hline 6 & ピラミーデ (オランダ) & 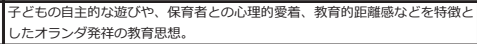 & $\%$ \\
\hline 7 & ペスタロッチ (スイス) & 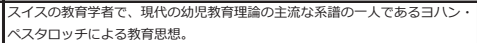 & $2.60 \%$ \\
\hline 8 & \multicolumn{2}{|r|}{ 倉橋㬱 } & $24.70 \%$ \\
\hline
\end{tabular}

※1 本稿では保育・教育思想の呼称を，思想の提唱者，思想家、メッッドなどの通称名を用いる 22$) 。$ ※2 ハンガリーのマイバ保育園を中心とした保育実践を本稿ではハンガリーの保育実践と総称する。

\section{図 1 採用される教育思想の内訳}

表 1 検証した文献リスト

\begin{tabular}{|l|l|l|}
\hline No. & \multicolumn{1}{|c|}{ 著作·文献 } & \multicolumn{1}{|c|}{ 著者 } \\
\hline M1 & モンテッソーリ·メソッド & モンテッソーリ \\
M2 & モンテッソーリ·メソッド入門 & 白川蓉子 \\
M3 & 幼児の秘密 & モンテッソーリ \\
M4 & いのちのひみつ & モンタナーロ \\
\hline H1 & ハンガリー保育園の教育プログラム & バゴニ,ザバディ \\
H2 & 新訂 乳児の保育·幼児の保育 & コダーイ芸術教育研究所 \\
\hline \multicolumn{2}{|l}{} \\
※
\end{tabular}



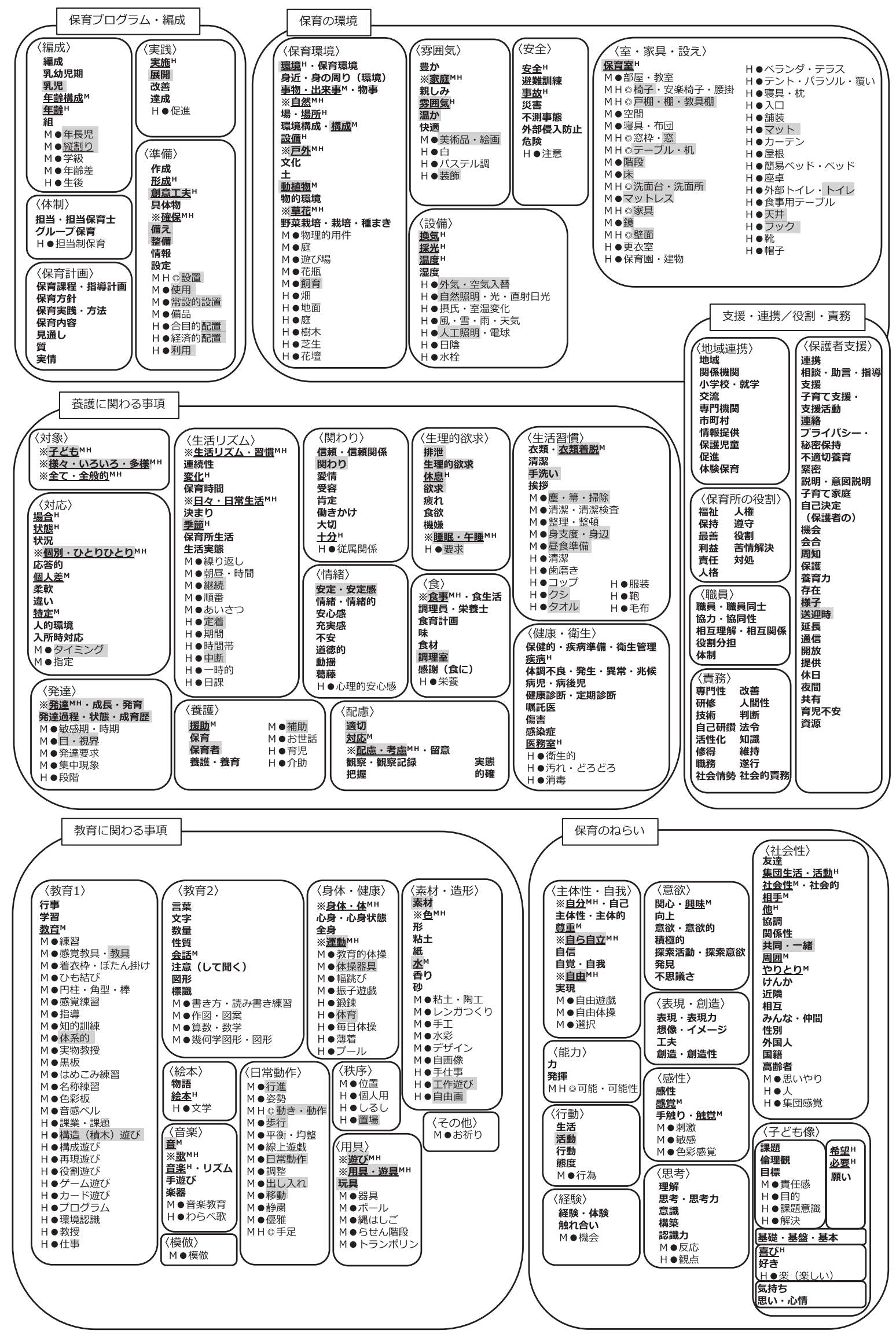

図 2 抽出された言語 $M \bullet:$ モンテッソーリ教育の出現言語 $H \bullet:$ ハンガリーの保育実践の出現言語 $M H$ : 両思想に出現する言語

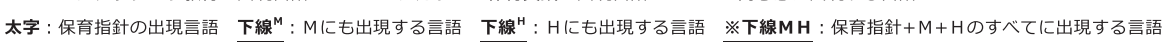
※網掛部の言語をキーワードとして表3のアンケート質問項目を作成した。 
4. 重要度・該当度の有意性にみる各思想の空間特性 4-1 検証方法

調查時に待機児童が多く確認された政令都市, 及び中核市に所在 する無作為に選出した保育施設 2,176 件 (全日本私立保育園連盟加 盟園）（表 2）を対象にアンケート調查を実施した。質問は, 前章で 各思想独自にみられた言語を各思想の保育・教育原理を表すもの(図 2 網掛部, 表 3 下線部）とみなして主に用い，保育施設の諸要室空 間や, 部分における空間特性の項目として作成した注 6)。各質問項目 につき,「重要視する」, 「該当する」かについて尋ね, 回答の割合を 各思想の実践園ごとと全体で示した（表 3)。さらに得られた回答の 有意性を $\mathrm{X}^{2}$ 検定を用いて検証した注7)。

表 2 アンケート調査の概要 調查期間: 平成27年 $11 \sim 12$ 月 方法: 郵送による配布. 回収 配布数

\begin{tabular}{|c|c|c|c|c|}
\hline 北海道・東北 & 札幌,仙台市 & 152 & 31 & 20.3 \\
\hline 関東 & 東京23区，川崎，横浜，相模原，千葉，さいたま市 & 745 & 123 & \\
\hline 中部 & 静岡,浜松,名古屋市 & 273 & 60 & 21.9 \\
\hline 近畿 & 京都，天阪，堺、神戸市 & 496 & 65 & 13.1 \\
\hline 中国 & 広島,棡山市 & 106 & 15 & 14.4 \\
\hline 九州 & 福岡,北九州,筸本,那覇霖 & 404 & 67 & 16.5 \\
\hline 不明 & & & 3 & \\
\hline 合計 & & 2176 & 364 & 16.7 \\
\hline
\end{tabular}

\section{4-2 各思想の実施園回答の有意性にみる空間特性の特異性}

$\mathrm{x} 2$ 検定の結果, 主に「乳児保育室」,「保育室の設え」,「家具」グ ループなどで有意差が多くみられた。モンテッソーリ教育実践園で 有意性を示した項目は, 「重要である」が 3 項目, 「該当する」が 14 項目であった。「40 歩行やつかまり立ち」,「41 視界に配慮する鏡」, $「 42$ 視界に配慮するモビール」など乳児の発達に応じた項目，「45 活動ごとのコーナー配置」、「48 壁や空向きの机」，「59 十分なフリ ースペース」など子どもの自己活動に伴う項目，「51 子ども用掃除 用具」, 「76 排泄時の着脱用ベンチ」の設置, 「72 スムーズな水まわ り」など，生活習慣の自立を促寸項目で特に有意であった。

ハンガリーの保育実践園で有意性を示した項目は，「重要である」 が 4 項目, 「該当する」が 22 項目とモンテッソーリ教育よりも多い 結果となった。「38月齢・動作別コーナー」,「56 造形コーナー」「58 休吿コーナー」などコーナー設置に関する項目,「15 登降園時集中 を妨げない」,「44 コーナーをまたぐ遊び」,「46 継続できる積木コ 一ナー」など遊びの継続性確保に関する項目, 「11, 17 家庭的䨌囲 気」など空間の雰囲気に関する項目，「60～62 専用室」などの専用 室確保に関する項目において特に有意であった。

以上の結果から, 有意性がみられたこれらの項目が, 各思想に基 づき保育をおこなう保育施設における空間特性の特異性であること が読み取られた。

\section{4-3 全体回答にみる各思想と「保育指針」の空間特性の共通性}

全体の保育施設で質問における回答の該当度が $80 \%$ 以上は 21 項 目, 該当度 $60 \%$ 以上は 48 項目であった。重要度・該当度共に $60 \%$ 以上の回答を示したのは, 全 86 項目のうち 23 項目にのぼった。質 問項目は前述のとおり, 主に両思想に独自の出現言語を用いて作成 したことから，保育・教育思想にみられる空間特性が，「保育指針」 に基づく保育を抗こなう一般園でも受け入れられていることが読み 取られた。従って, 各思想の空間特性の中にも「保育指針」と共通 性があることが確認できたといえる。
表 3 重要度・該当度の割合と $\times 2$ 検定による有意性

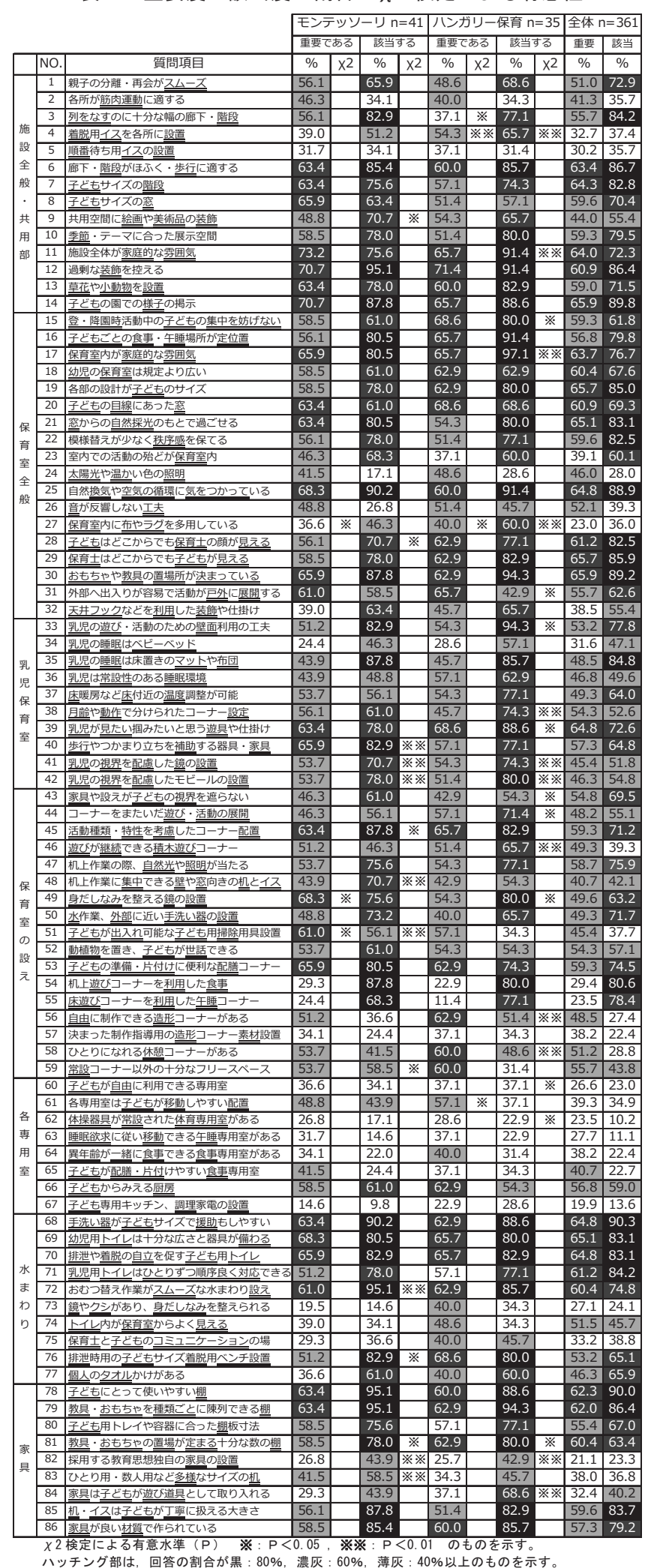

表 4 施設調査概要

\begin{tabular}{|c|c|c|c|c|}
\hline & 施設名 & 所在地 & 施設種別 & 定員 \\
\hline \multirow{5}{*}{$\Sigma$} & Ki 保育園 & 神奈川県横浜市 & 認可保育所 & 90 名 \\
\hline & 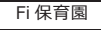 & 神奈川県茅崎市 & 認可保育所 & 130 名 \\
\hline & Mu 保育園 & 神奈川県相模原市 & 認可保育所 & 90 名 \\
\hline & Em 保育園 & 福岡県福岡市 & 認可保育所 & 270 名 \\
\hline & Ka 保育園 & 千葉県八千代市 & 認可保育所 & 120 名 \\
\hline \multirow{2}{*}{$I$} & Kas 保育園 & 東京都多摩市 & 認可保育所 & 180 名 \\
\hline & Ya 保育園 & 兵庫県姬路市 & 認定こども園 & 95名 \\
\hline
\end{tabular}




\section{5． 実施園の空間事例にみる各思想の空間特性}

表 5 では, 前章のアンケート調査でモンテッソーリ教育, ハンガ リーの保育実践のそれぞれが特異性を示した空間特性と，一般園で も受入れられている項目，すなわち全体回答の「重要度」「該当度」 が 60\%以上の空間特性を整理してまとめたうえで, 各思想を採用す る保育施設, 計 7 園（表 4）を対象とした施設調査で得られた実際 の空間事例を提示した注8)。
各思想に基づいた空間特性のなかで，一般園でも受入られるもの として，共用部における各部設計，装飾などによる雾囲気づくり， 採光・換気，保育室における視認性や空間規模の検討，水まわりに おける動線計画や規模の検討, 家具設計への配慮などがあり（表 5), 施設調查では, 幾つかの事例がみられた (写真 W-1〜4)。これらは, 一般園にとっても導入しやすい空間的工夫であるといえる。

表 5 空間特性が反映された空間事例

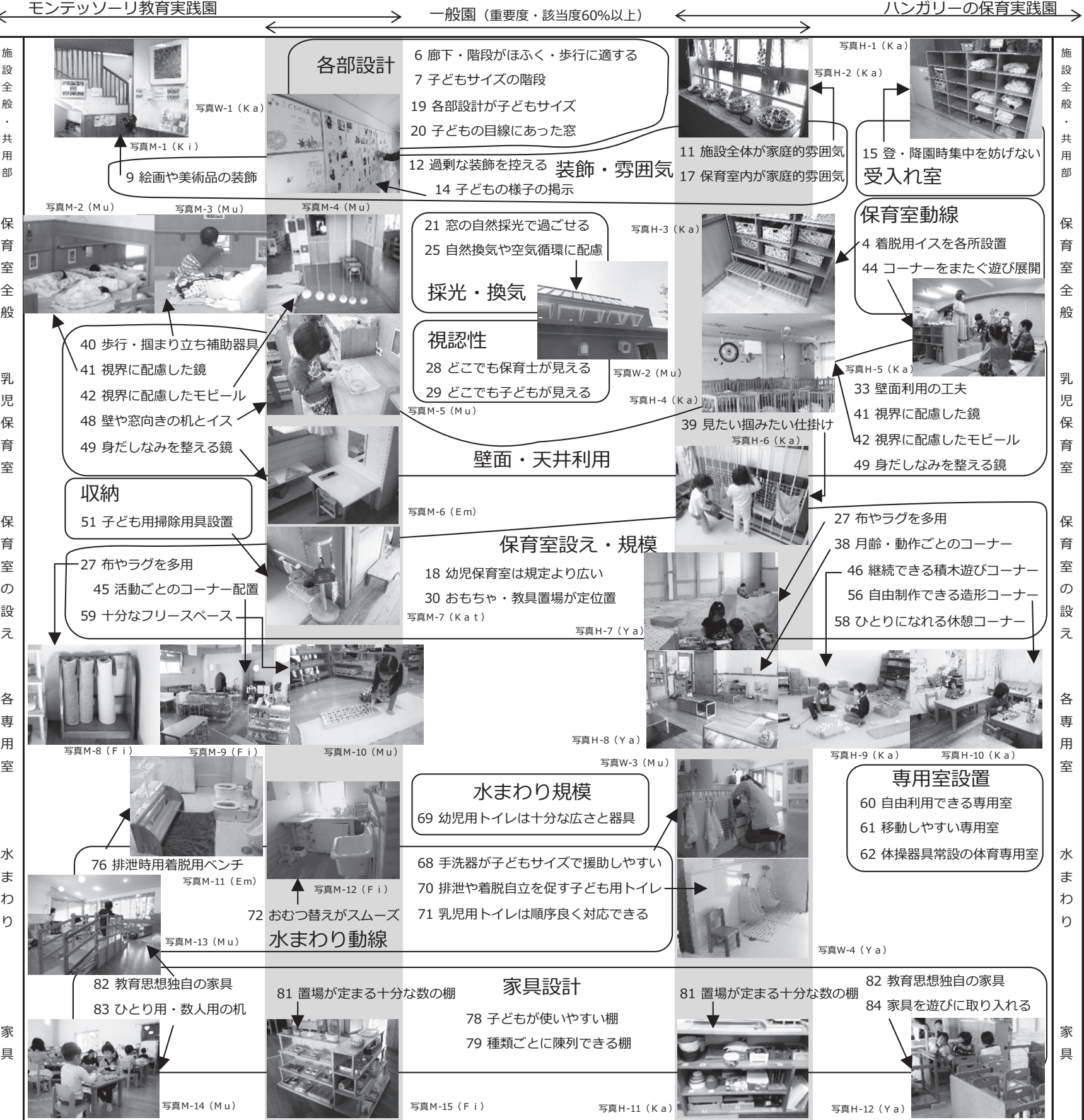

※（）内は調査を実施した表 4 の施設名を表す。※ハッチング部は各思想に有意性がみられた空間特性で，かつ一般園でも重要度・該当度が $60 \%$ 以上であったもの。

思想に基づく空間特性を，実際の空間に反映する際のそれぞれの 思想の実施園での工夫を，思想ごとに以下に考察する。
モンテッソーリ教育実施園では，乳児保育室に歩行・掴まり立ち 用の手すりの設置や，睡眠スペース周辺の鏡，モビールの設置への 
対応として，保育室における壁面・天井面の利用や工夫がみられた (写真 M-2〜6)。保育室では主に教具を用いた子どもの自己活動が 中心となるため, 活動ごとのコーナー設置, 床作業用フリースペー スが常設的に要求される（写真 M-9，10）。 Fi， Mu 両保育園では, ランチルームを確保して模様替えをおこなわないことで，室内の常 設性を確保していたが，模様替えを要する場合には，保育室の十分 な空間規模の検討が必要といえる。教具は種類, 段階ごとに定位置 に陳列され (M-15), ひとり用, 数人用 (M-14), 対面, 壁向き (M-5) などの多様な家具や設えが，意図する教育活動の提供につながって いた。また，保育室内の子ども用掃除用具 (写真 M-7), 水まわり の排泄時用着脱ベンチ (写真 M-11) などは $5 つ の$ 全ての実施園で, 行為, 活動と近接する位置に備えられていた。

ハンガリーの保育実践園では, 家庭的な雰囲気づくりがなされて おり，Ka 保育園では各所にカウンターを設えて装飾を施し，雾囲 気づくりに取り組む様子がみられた (写真 H-2)。乳児保育室ではモ ビール（写真 H-4）, 壁面の仕掛け（写真 H-6）など, モンテッソー リの場合と同様に，壁面・天井を利用した発達ごとの設えの工夫が みられた。保育室では子どもの主体的遊びが中心となり，特に遊び の継続性が重要視される。そのため, 積木（写真 H-9）コーナーを はじめ, 各コーナーの常設設置が可能な空間規模の検討や, 遊びが コーナーをまたいで展開するような, 子どもの動線計画への配慮が 必要であるといえる。また Ka 保育園では, 造形コーナー(写真 H-10) の机・イスを食事コーナーとして転用することで, 保育室内の常設 性を確保していた。遊びの広がりのなかで, 家具を取り入れて展開 できるよう，Ya保育園では，子どもが扱いや寸い家具を選定し，備 える様子がみられた（写真 H-12）。さらに，登降園時において，子 どもの遊びの集中が妨げられない配慮として, 調查した 2 園ではい ずれも, 保育室に隣接する受入室を完備し対応していた(写真 H-1)。

各思想に特異性を示した空間特性ではあるが，上記の空間事例を みると，なかには「保育指針」に基づく空間づくりにおいても，導 入できる工夫もあるのではないかと考えられた。

\section{6. まとめと今後の課題}

本稿では保育現場で採用事例が多くみられるモンテッソーリ教育, ハンガリーの保育実践のふたつの思想に着目し，これらの思想に基 づく空間特性が「保育指針」に基づく空間づくりのひとつの在り方 となり得るかを明らかにすることを目的として，文献や記述からの 出現言語，アンケート調查，空間事例による分析をおこない，次の ような結果を得た。

(1)出現言語の分析では,「保育の環境」や「教育」などのグループ で抽出された独自の出現言語が各思想の基本原理における特異性を 示寸ものである点，「保育指針」と各思想に幾つかの共通言語がみら れたことから，「保育指針」が各思想を包含するものである点が示唆 された。

(2)出現言語分析で抽出された各思想独自の言語を用いて, 空間特 性に関する質問項目を作成してアンケート調查を実施し，実施園の 回答の有意性から各思想の空間特性の特異性を，全体回答から各思 想と「保育指針」との空間特性の共通性をみた。その結果,「乳児保 育室」,「保育室の設え」,「家具」グループなどの項目で，各思想の 実施園に幾つかの有意性が確認でき，これらが保育施設の空間特性
における，思想ごとの特異性である可能性を示した。また各思想に 基づく空間特性のうち, 一般園でも受け入れられる項目がみられた ことから，各思想の空間特性の中に「保育指針」との共通性がある ことが確認できた。

(3)施設調査では，各思想の特異性を示した空間特性が各思想の実 施園において確認できた。これらの空間事例を通して, 空間特性が 実際の空間に反映される際の具体例を提示できた。また，それぞれ の思想に基づく空間事例であっても，なかには一般園でも導入でき る工夫もあるのではないかと考えられた。

本稿では，モンテッソーリ教育，ハンガリーの保育実践の空間特 性における特異性を, 少ないながらも確認することができた。また, 各思想に基づいた空間特性のなかには，「保育指針」に基づき保育を おこなう一般園でも導入されや寸い項目も認められた。以上のこと から，各思想に基づく空間が，一般園における良質な空間づくりの ヒントとなる示唆を含むものであったといえる。

「保育指針」は本稿で着目したふたつの思想を含め,ささざまな 保育・教育思想を包含しているとも考えらえる。日本の保育現場で は多様な思想が採用されることから，今後は，他の思想も含め, さ まざまな規模や実践度での空間事例の検証を通じた研究の蓄積を図 っていくことが課題である。

\section{謝辞}

研究助成を頂きました一般財団法人第一生命財団および，調查にご 協力を頂きました皆様に深く感謝申し上げます。

\section{参考文献}

1）民秋言 : 幼稚園教育要領・保育所保育指針の変遷と幼保連携型認定こど も園教育・保育要領の成立, 萌文書林, 2014

2) 厚生労働省 : 保育所保育指針解説書, フレーベル館, 2008

3）内閣府, 文部科学省, 厚生労働省 : 幼保連携型認定こども園教育・保育 要領解説, 2015

4）今川峰子:幼稚園児の社会的行動に影響寸る保育空間と保育理念, MERA Journal=人間・環境学会誌 $2(2), p p .21-27,1996.6$

5）遠矢容子，小野理映子，小川信子：保育施設空間に関寸る研究・その 1 一保育方法と保育空間の関わり一, 日本建築学会大会学術講演梗概集, E-1 分冊, pp.175-176, 1996

6）細谷俊子，積田洋，鶴崎有：保育園の室内遊びにおける異年齢交流と室 内構成との相関分析, 日本建築学会計画系論文集, 第 639 号, pp.1029-1035, 2009.5

7）西本雅人, 河合慎介, 田和佐知子 : 異年齢保育における保育室のコーナ 一設定の変更サイクルに関する研究一京都府近郊の保育施設での異年齢保 育におけるコーナー設定のケーススタディー, 日本建築学会大会学術講演 梗概集，建築計画，pp.401-402, 2014

8）伊藤有宏 : フリードリッヒ・フレーベルと建築ーフレーベルの構想した 幼稚園建築とその環境の考察一, 日本建築学会大会学術講演梗概集, E-1 分冊, pp.291-292, 1998

9）川上正倫，伊藤泰彦，千田満，矢田努：日本におけるシュタイナー幼児 教育空間に関する研究一教育理念と空間の関係性について一, 日本建築学 会大会学術講演梗概集，E-1 分冊, pp.293-294, 1998

10）神成健, 初見学: モンテッソーリ教育と幼稚園の計画一オープンエジュ ケーションと幼稚園の計画に関する研究一, 日本建築学会関東支部研究報 告集，第 55 号，pp.281-284，1984.7

11）高橋節子, 元岡展久：モンテッソーリ保育所における物理的環境一非モ ンテッソーリ保育所との比較による検討一，日本建築学会技術報告集，第 44 号, pp.207-212, 2014.2

12）橋本都子，中田和葉，高橋鷹志：レッジョ・エミリアの幼稚園に関する 調査報告一イタリアの教育施設に関する研究その 1 -, 日本建築学会大会 学術講演梗概集, 建築計画, pp.177-178, 2012 
13）山田朝子, 千島亜美, 本杉一磨, 真崎学, 初見学, 垣野義典, 松田雄二 : フィンランド幼保一体型保育施設の平面構成から見る空間特性ーフィンラ ンドの就学前保育施設 [パイバコティ]に関する研究 その 1 - , 日本建築学 会大会学術講演梗概集, E-1 分冊, pp.147-148, 2011

14）本杉一磨, 他 : チーム保育の実践と保育者の見守りから見る空間特性一 フィンランドの就学前保育施設 [パイバコティ]に関する研究 その $2-$, 日 本建築学会大会学術講演梗概集, E-1 分冊, pp.149-150, 2011

15）千島亜美，他 : 異年齢グループ保育の活動実態を背景とした子どもの活 動から見る空間特性ーフィンランドの就学前保育施設 [パイバコティ]に関 する研究 その 3 -, 日本建築学会大会学術講演梗概集, E-1 分冊, pp.151-152, 2011

16）モンテッソーリ，M. : モンテッソーリ・メソッド，明治図書出版， 1974

17）白川蓉子：「モンテッソーリ・メソッド」入門, 明治図書出版, 1986

18）モンテッソーリ，M. : 幼児の秘密，国土社，1968

19）モンタナーロ, S. : いのちのひみつ, KTC 中央出版, 2003

20）バコニ, P.他: ハンガリー保育園の教育プログラム, 明治図書出版, 1974

21）コダーイ芸術教育研究所 : 新訂乳児の保育・幼児の保育, コダーイ芸術 教育研究所, 1990

22）谷田貝公昭 : 新版 ・保育用語辞典, 2016

注

注 1) 保育施設はその施設形態により, 幼稚園教育要領, 幼保連携型認定こど も園教育・保育要領，保育所保育指針に基づき保育をおこなっているが， 本稿では主に保育所保育指針を中心にとりあげている。

注 2）保育所保育指針はその冒頭（保育指針第 1 章 $1(2))$ で，「各保育所は, この指針において規定される保育の内容に係る基本原則に関する事項等を 踏まえ, 各保育所の実情に応じて創意工夫を図り，保育所の機能及び質の 向上に努めなければならない」とし，保育形態や内容といった保育実践の 具体的方法論は, 個々の保育所の裁量に委祇ている。

注 3)アメリカでは，幼児版保育環境評価スケール ECERS (Early Childhood Environment Rating Scale), 乳児版保育環境評価スケール ITERS (Infant and Toddler Environment Rating Scale）などの保育環境評価スケールが 開発され，個別の保育プログラムでの自己評価や保育の質向上に用いられ ている。評価項目には空間や家具に関する項目も含まれている。

注 4) 本稿における「空間特性」とは, 言語表現を用いた, 保育施設の諸要室, 家具などにおける空間・部分の状態や有様を意味する。保育・教育思想に よる特性をみるという観点から，敷地条件や関係法令等により影響を受け ると思われる配置計画, 建物規模などは対象としていない。

注 5) 本稿では，日本の保育施設における応用という観点から，保育・教育思 想の基本原理を基に日本の保育施設で独自に普及・発展した保育・教育思 想を主に扱う。従って調査対象を, 原理主義的に実践するハンガリー国内 の保育施設とはしていない。

注 6) 質問項目作成上，同義の別の名詞や文章として言い換えたものもある。

注 7) $\chi 2$ 検定は，(1)モンテッソーリ教育実施園とそれ以外の全て,(2)ハンガリ 一の保育実践実施園とそれ以外の全て,の比較によるものである。

注 8) 提示した事例は, 施設調査において実践のみられたもののみであり,有意 性がみられた全ての項目ではない。 


\section{SPATIAL CHARACTERISTICS OF CHILD CARE FACILITIES \\ WHICH BASED ON A THOUGHT OF CHILD CARE AND EDUCATION}

Case study on the Montessori education and the Hungarian childcare practice theory

\section{Kazuko SHIRAKAWA* and Mariko SADAYUKI**}

* Grad. Student, Graduate School of Human Life Science, Division of Living Environment, Japan Women's University, M. Eng.

** Prof., Dept. of Housing and Architecture, Japan Women's University, Dr. Eng.

The purpose of this research is to provide spatial characteristics which based on childcare and educational ideals of each child care facilities. In this study particularly focuses on "The Montessori education" and "The Hungarian childcare practice theory" which are highly adopted in Japan. To know the spatial characteristics of each educational thought, we analyzed by appearance languages from descriptions of which each method and "A national guideline for daycare center for children ("a national nursing guideline") ", questionnaires and field surveys. The results of these analyses are as follows.

1. There are many common appearance languages between an each educational thought and "a national nursing guideline". It is also found that there are several original languages of an each educational thought, such as "environment of nursing" and "education techniques". It means that the same concept is included in an each educational thought and "a national nursing guideline".

2. Referring to appearance languages from descriptions, a questionnaire survey is conducted. As a result, "baby nursery room", "equipment in the nursery room" and the "furniture" groups are mainly significant difference from the general child care facilities. This research figures out original spatial characteristic which required by these two educational thought. Also, among the spatial characteristics based on each educational thought, items that can be accepted in general child care facilities were also seen, so it was confirmed that there is commonality with the "childcare guidelines" among the spatial characteristics of each educational thought.

3. In the field surveys, it makes clearly that original spatial characteristic is reflected in a space by actual each educational thought facilities.

In this research, several significant differences in the spatial characteristics of the Montessori education and the Hungarian childcare practice are indicated by questionnaires. And it can be said that the spatial characteristics based on each educational thought, items that are easy to accept even in general child care facilities. From the above, it can be said that space making intended along a concept of special educational thought could be also evaluated as one of the space which based on "a national nursing guideline". It should be important for the child care facilities with high quality of good nursing and educational environment to know the basic spatial characteristics of each educational thought by a number of case studies on the various scales and the degree of practice. 